\title{
Fragmentation of Cationized Phosphotyrosine Containing Peptides by Atmospheric Pressure MALDI/Ion Trap Mass Spectrometry
}

\author{
Susanne C. Moyer, ${ }^{*}$ Christopher E. VonSeggern, and Robert J. Cotter \\ Department of Pharmacology and Molecular Sciences, Johns Hopkins University School of Medicine, \\ Baltimore, MD, USA
}

\begin{abstract}
An investigation of phosphate loss from sodium-cationized phosphotyrosine containing peptide ions was conducted using liquid infrared $(2.94 \mu \mathrm{m})$ atmospheric pressure matrixassisted laser desorption/ionization (AP MALDI) coupled to an ion trap mass spectrometer (ITMS). Previous experiments in our laboratory explored the fragmentation patterns of protonated phosphotyrosine containing peptides, which experience a loss of $98 \mathrm{Da}$ under CID conditions in the ITMS. This loss of $98 \mathrm{Da}$ is unexpected for phosphotyrosine, given the structure of its side chain. Phosphate loss from phosphotyrosine residues seems to be dependent on the presence of arginine or lysine residues in the peptide sequence. In the absence of a basic residue, the protonated phosphotyrosine peptides do not undergo losses of $\mathrm{HPO}_{3}(\Delta 80 \mathrm{Da})$ nor $\mathrm{HPO}_{3}+\mathrm{H}_{2} \mathrm{O}(\Delta 98 \mathrm{Da})$ in their CID spectra. However, sodium cationized phosphotyrosine containing peptides that do not contain arginine or lysine residues within their sequences do undergo losses of $\mathrm{HPO}_{3}(\Delta 80 \mathrm{Da})$ and $\mathrm{HPO}_{3}+\mathrm{H}_{2} \mathrm{O}(\Delta 98 \mathrm{Da})$ in their CID spectra. (J Am Soc Mass Spectrom 2003, 14, 581-592) (c) 2003 American Society for Mass Spectrometry
\end{abstract}

$\mathrm{M}$ ass spectrometry has become a powerful tool for diagnostic proteomics and is a leading technique for structural determination [1]. The growing recognition that the proteome is not a static entity has placed greater emphasis on identifying post-translational modifications. These modifications are proving to be important regulators in cellular activity and are crucial for a complete understanding of the proteome. Mass spectrometry is the leading analytical technique for the determination of posttranslational modifications [2]. As proteomic techniques become more automated, the need for full understanding of potential gas phase fragmentation patterns is vital to rapid identification of structural components [3]. Post-translational modifications prove to be a challenge in the creation of structural databases [2]. Complete understanding of protein function can be gained through careful analysis of post-translational modifications.

Phosphorylation is one of the most common and physiologically important post-translational modifications in proteins and peptides. The ubiquitous nature of phosphorylation in biological systems has necessitated

Published online April 17, 2003

Address all reprint requests to R. J. Cotter, Department of Pharmacology and Molecular Sciences, Johns Hopkins University School of Medicine, 725 N. Wolfe St., B-7 Biophysics Building, Baltimore, Maryland, USA, 21205. E-mail: rcotter@jhmi.edu

*Also of the Department of Chemistry, Johns Hopkins University, Baltimore, MD, USA. the development of methods for the identification and characterization of phosphorylation sites. Several groups have studied the gas phase dephosphorylation of phosphorylated peptide and protein ions using electrospray ionization (ESI) or matrix-assisted laser desorption/ionization (MALDI) mass spectrometry [4-17]. Annan and Carr examined phosphopeptide ion fragmentation by postsource decay (PSD) time-of-flight (TOF) mass spectrometry and found that phosphoserine and phosphothreonine containing peptides produced abundant $\left[\mathrm{MH}-\mathrm{H}_{3} \mathrm{PO}_{4}\right]^{+}$ions and less abundant $\left[\mathrm{MH}-\mathrm{HPO}_{3}\right]^{+}$ions [5]. Conversely, their PSD data for phosphotyrosine containing peptides showed predominantly $\left[\mathrm{MH}-\mathrm{HPO}_{3}\right]^{+}$ions and rarely revealed $[\mathrm{MH}-$ $\left.\mathrm{H}_{3} \mathrm{PO}_{4}\right]^{+}$ions. PSD fragmentation patterns revealing losses of either 80 or 98 Da have been used to determine whether an aromatic or aliphatic phosphorylation site is present within a peptide sequence [18].

However, Qin and Chait reported that the MALDI/ ITMS CID spectra of protonated phosphotyrosine peptides showed a loss of $98 \mathrm{Da}$ from their molecular ions, corresponding to either a loss of $\mathrm{H}_{3} \mathrm{PO}_{4}$ or $\mathrm{HPO}_{3}$ $+\mathrm{H}_{2} \mathrm{O}$ [7]. DeGnore and Qin [8] later studied the CID spectra of phosphopeptides by ESI/ITMS. They reported that the loss of phosphate group is charge state dependent and that loss of $98 \mathrm{Da}$ from a phosphotyrosine containing peptide ion was most likely the result of a two-step process involving the loss of $\mathrm{HPO}_{3}$ followed by the loss of $\mathrm{H}_{2} \mathrm{O}$ elsewhere in the peptide. 
Recently, Metzger and Hoffman [12] proposed two intriguing mechanisms to explain the loss of $\mathrm{H}_{3} \mathrm{PO}_{4}$ from phosphotyrosine containing peptide ions under MALDI PSD conditions. The first mechanism involves the transfer of $\mathrm{HPO}_{3}$ to an aspartic acid side chain, followed by a cleavage of $\mathrm{H}_{3} \mathrm{PO}_{4}$ and subsequent formation of a succinimide. The second mechanism entails protonation of the phosphate group of phosphotyrosine by an arginine residue followed by the loss of $\mathrm{H}_{3} \mathrm{PO}_{4}$ resulting in a phenyl cation on the tyrosine residue. Later work by Moyer et al. also reported that the CID fragmentation of protonated phosphotyrosine containing peptides resulted in loss of $98 \mathrm{Da}$, but suggested that this occurs only when there is an arginine or lysine residue present in the peptide sequence [19]. Their results would suggest that the loss of $98 \mathrm{Da}$ from phosphotyrosine containing peptides could be the result of either charge remote or charge directed fragmentation processes, rather than a rearrangement.

The AP-MALDI/ITMS configuration has proven to be useful in obtaining structural information for peptides and protein digests [19-23] as well as for the identification and characterization of posttranslational modifications [23]. Recent work in our laboratory has demonstrated the utility of infrared AP-MALDI/ITMS using an Er:YAG laser $(2.94 \mu \mathrm{m})$ for the analysis of carbohydrates [24] and posttranslationally modified peptides [25]. The infrared AP-MALDI/ITMS instrument is capable of utilizing liquid matrices, such as glycerol. The glycerol matrix produces protonated, sodiated and potassiated ions as well as sodium and potassium salts.

In the present work, liquid infrared $(2.94 \mu \mathrm{m}) \mathrm{AP}$ MALDI was utilized to evaluate the effect of alkali metal cation attachment on the gas phase dephosphorylation patterns of phosphotyrosine containing peptides under collision induced dissociation (CID) conditions. While previous work suggests that phosphate loss from phosphotyrosine residues is dependent on the presence of arginine or lysine residues in the peptide sequence, we now show similar CID fragmentation behavior of sodium and potassium cationized phosphotyrosine-containing peptides.

\section{Experimental Section}

\section{Peptides}

The peptide SVL(pY)TAVQPNE was purchased from AnaSpec (San Jose, CA). All other peptides were synthesized at the Peptide Synthesis Core Facility (Johns Hopkins University School of Medicine, Baltimore, $\mathrm{MD}$ ). All peptides were dissolved in $18 \mathrm{M} \Omega$ water to a concentration of $100 \mu \mathrm{M}$.

\section{Liquid AP-MALDI Matrix}

Glycerol was obtained from Sigma (St. Louis, MO) and used without further purification.

\section{Liquid Infrared AP-MALDI/ITMS}

Mass spectra were obtained on a LCQ quadrupole ion trap mass spectrometer (ThermoFinnigan, San Jose, CA) equipped with a modified commercial atmospheric pressure matrix-assisted laser desorption/ionization (AP-MALDI) source (Mass Technologies, Burtonsville, MD). The source is equipped with a Bioscope UV+ laser (Bioptic Lasersysteme, Berlin, Germany) that has both a Nd:YAG laser at $355 \mathrm{~nm}$ and an Er:YAG laser at $2.94 \mu \mathrm{m}$. The laser was focused onto the MALDI target with a sapphire lens $(\mathrm{F}=150 \mathrm{~mm})$. For this work, the Er:YAG laser was utilized. The Er:YAG laser generated approximately $30 \mathrm{~ns}$ pulses at $5 \mathrm{~Hz}$ with approximately $400 \mu \mathrm{J} /$ pulse. The laser was run asynchronously with the trapping cycle and spectra were acquired at $300 \mathrm{~ms}$ per scan. A potential of 2.5 $\mathrm{kV}$ was applied between the sample target and the inlet capillary. The transfer capillary temperature was set to $200{ }^{\circ} \mathrm{C}$. Samples were prepared by mixing approximately $1 \mu \mathrm{L}$ of glycerol with $1 \mu \mathrm{L}$ of analyte solution on the AP-MALDI target plate. The resulting mixture was then was then analyzed in liquid form by infrared AP MALDI/ITMS.

\section{Results and Discussion}

In the present study, the low energy gas phase CID fragmentations of phosphotyrosine containing peptides resulting from sodium and potassium attachment were studied. In previous work, it was demonstrated that protonated phosphotyrosine containing peptides would undergo a loss of $98 \mathrm{Da}$, corresponding to a loss of $\mathrm{HPO}_{3}+\mathrm{H}_{2} \mathrm{O}$, if the peptide sequence also contained an arginine or lysine residue [19]. If the peptide contained only one arginine residue in its sequence, losses of both 80 and $98 \mathrm{Da}$, corresponding to losses of $\mathrm{HPO}_{3}$ and $\mathrm{HPO}_{3}+\mathrm{H}_{2} \mathrm{O}$, respectively, were evident in the CID spectra. However, peptide sequences with a lysine residue or two or more arginine residues would display only the loss of 98 Da. Conversely, protonated phosphotyrosine containing peptides that did not possess a basic arginine or lysine residue did not undergo losses of 80 or 98 $\mathrm{Da}$ in their CID spectra. This was even the case in peptides that contained several acidic residues (aspartic or glutamic acids) in their sequence. This finding is in contrast with the mechanism postulated by Metzger and Hoffman [12], where a loss of $\mathrm{H}_{3} \mathrm{PO}_{4}$ (98 Da) from a phosphotyrosine containing peptide proceeds through transfer of $\mathrm{HPO}_{3}$ from the phosphotyrosine side chain to an aspartic acid side chain followed by elimination of $\mathrm{H}_{3} \mathrm{PO}_{4}$ from the aspartic acid side chain and the resulting succinimide formation. However, other data presented by Metzger and Hoffman displayed compelling evidence that the loss of $98 \mathrm{Da}$ from a phosphotyrosine containing peptide was the result of a loss of $\mathrm{HPO}_{3}$ from the phosphotyrosine residue and $\mathrm{H}_{2} \mathrm{O}$ from elsewhere in the 

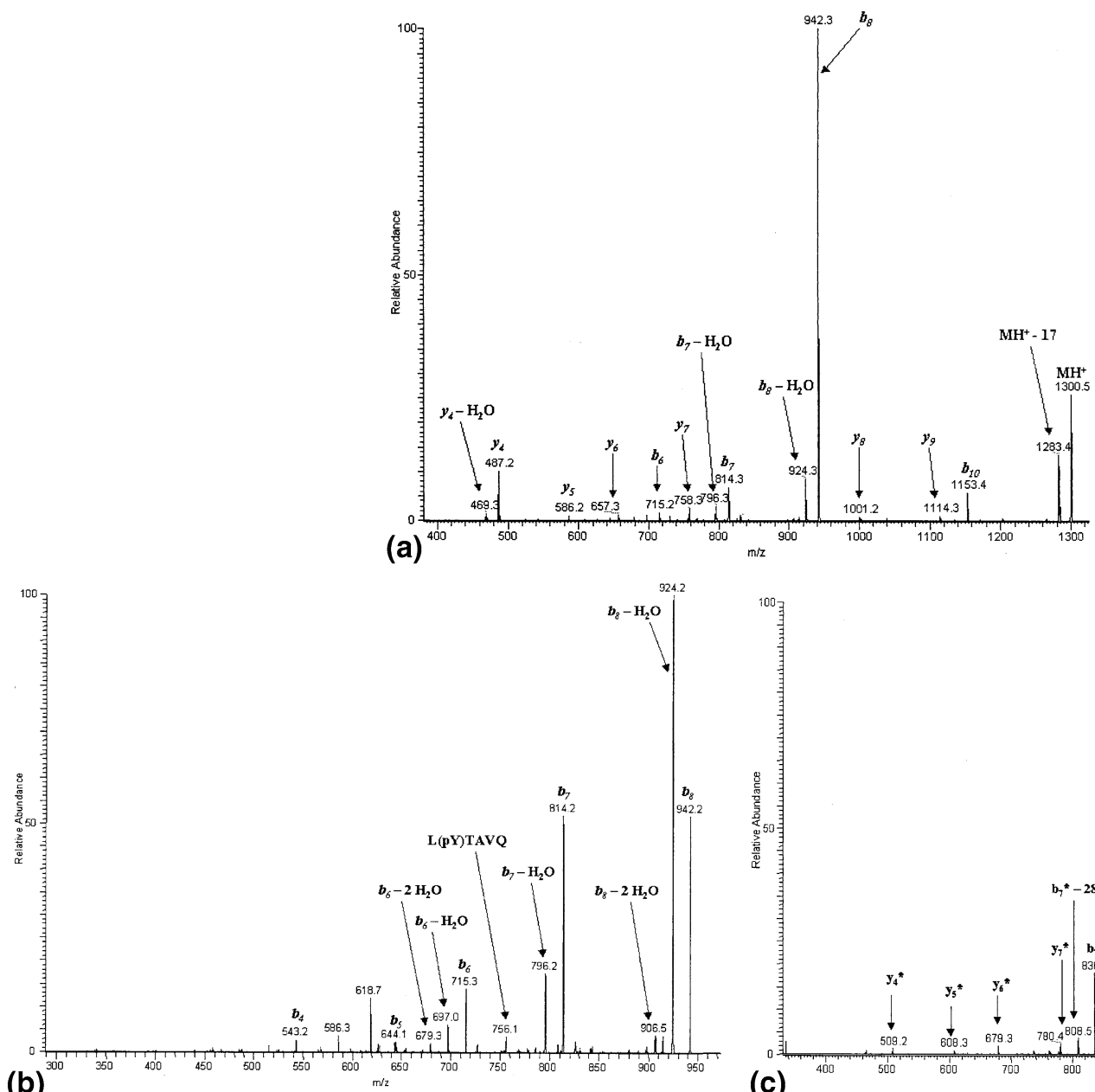

(b)

Figure 1. (a) $\mathrm{MS}^{2}$ of the $[\mathrm{M}+\mathrm{H}]^{+}$ion of SVL(pY)TAVQPNE at $m / z 1300$. No loss of phosphate is observed in this spectrum, (b) MS ${ }^{3}$ of the $b_{8}$ ion of SVL(pY)TAVQPNE at $m / z$ 942. No loss of phosphate is observed in this spectrum, (c) $\mathrm{MS}_{2}$ of the $[\mathrm{M}+\mathrm{Na}]^{+}$ion of SVL(pY)TAVQPNE at $\mathrm{m} / z$ 1322. The asterisks $\left(^{*}\right)$ indicate a sodiated ion. Losses of 80 and 98 Da from the sodium cationized parent ion, corresponding to losses of $\mathrm{HPO}_{3}$ and $\mathrm{HPO}_{3}+\mathrm{H}_{2} \mathrm{O}$, respectively, are observed

peptide. In that work, they deuterated the phenyl ring of a phosphotyrosine residue. A loss of $99 \mathrm{Da}$ in the fragmentation spectrum could indicate that $\mathrm{H}_{2} \mathrm{DPO}_{4}$ was eliminated from the phosphotyrosine side chain, whereas a loss of 98 Da would signify losses of $\mathrm{HPO}_{3}$ from the phosphotyrosine side chain and $\mathrm{H}_{2} \mathrm{O}$ from another location within the peptide; their PSD data revealed a loss of $98 \mathrm{Da}$.

Our previous findings suggest that arginine and lysine residues may play a role in the elimination of $\mathrm{HPO}_{3}$ from a phosphotyrosine residue via a charge remote or charge induced fragmentation process [19]. Charge-remote fragmentation is described as a class of gas-phase decompositions that occur at a location that is physically remote from the charge site [26-29]. Charged-induced fragmentations occur when a direct interaction between the charge site location and the site of fragmentation initiates fragmentation at that site [26]. According to Gross [30], charge-remote fragmentation usually occurs under high energy CID conditions, however it is possible for these types of reactions to occur under low energy CID or metastable decay processes.

Several researchers have noted losses of $\mathrm{HPO}_{3}$ from protonated phosphotyrosine peptides in low energy CID or PSD spectra $[5,7-9,12,14]$. However these peptides all contained an arginine or lysine in their sequences. Fragmentation of a protonated peptide proceeds differently when a peptide sequence is devoid of arginine or lysine residues. In previous work [19], we showed that the protonated peptides, AALIEDA E(pY)AAAG, AAAAADAA(pY)AAAA and SV L(pY)TAVQPNE, as well as the tryptic digest fragment, $\mathrm{V}(\mathrm{pY}) \mathrm{IHPF}$, did not lose $\mathrm{HPO}_{3}$ in their CID fragmentation spectra. Figures 1a and $1 \mathrm{~b}$ show the MS/MS and the $\mathrm{MS}^{3}$ spectra of the protonated peptide, SV $\mathrm{L}(\mathrm{pY}) \mathrm{TAVQPNE} . \mathrm{HPO}_{3}$ is not eliminated from the protonated peptide ion under low-energy CID condtions. When the $[\mathrm{M}+\mathrm{Na}]^{+}$ion at $m / z 1322$ (Figure 1c) 

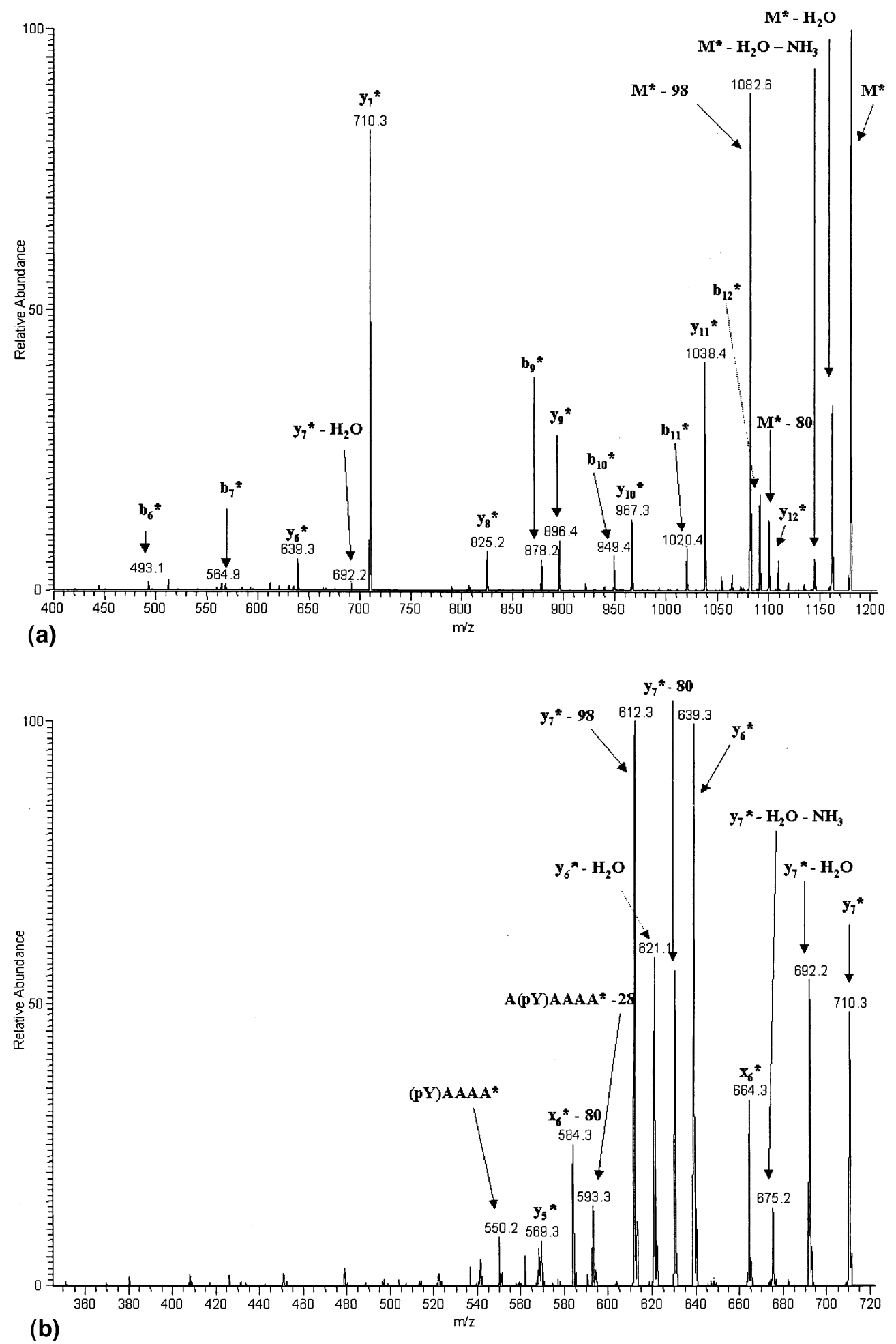

Figure 2. (a) $\mathrm{MS}^{2}$ of the $[\mathrm{M}+\mathrm{Na}]^{+}$ion of AAAAADAA(pY)AAAA at $m / z 1180$. The asterisks $\left(^{*}\right)$ indicate a sodiated ion. (b) $\mathrm{MS}^{3}$ of the sodiated $y_{7}$ ion of AAAAADAA(pY)AAAA at $m / z$ 710. The asterisks $\left(^{*}\right)$ indicate a sodiated ion.

and the $[\mathrm{M}+\mathrm{K}]^{+}$ion at $m / z 1338$ (data not shown) of SVL(pY)TAVQPNE are analyzed by CID, fragment ions corresponding to losses of 80 and $98 \mathrm{Da}\left(\mathrm{HPO}_{3}\right.$ and $\mathrm{HPO}_{3}+\mathrm{H}_{2} \mathrm{O}$, respectively) are observed.
Figure $2 \mathrm{a}$ is the MS/MS spectrum of the $[\mathrm{M}+\mathrm{Na}]^{+}$ ion of AAAAADAA(pY)AAAA at $m / z$ 1180. The two predominant fragment ions in this spectrum are the $[\mathrm{M}+\mathrm{Na}-98]^{+}$ion at $\mathrm{m} / z 1082$ and the sodiated $y_{7}$ ion at 
Table 1. CID Fragmentations of C-fragmentations of C-terminally amidated phosphotyrosine peptides

\begin{tabular}{|c|c|c|}
\hline & $\mathrm{AAA}(\mathrm{pY}) \mathrm{AAA}-\mathrm{NH}_{2}$ & AAAYAAA- $\mathrm{NH}_{2}$ \\
\hline $\mathrm{MS}^{2}$ of $[\mathrm{M}+\mathrm{H}]^{+}$ & $\begin{array}{l}\Delta \mathrm{NH}_{3}, \Delta\left(\mathrm{NH}_{3}+\mathrm{H}_{2} \mathrm{O}\right), x_{6}, b_{6}, a_{6} \text { or } x_{6}, y_{5} \text { or } c_{5}, b_{5}, y_{4} \text { or } c_{4}, b_{4} \\
\quad \text { or } \mathrm{A}(\mathrm{pY}) \mathrm{AA} \text { or } \mathrm{AA}(\mathrm{pY}) \mathrm{A}, \mathrm{A}(\mathrm{pY}) \mathrm{A} \text { or } \mathrm{AA}(\mathrm{pY}) \text { or }(\mathrm{pY}) \mathrm{AA}\end{array}$ & $\Delta \mathrm{NH}_{3}, \Delta\left(\mathrm{NH}_{3}+\mathrm{H}_{2} \mathrm{O}\right), \Delta \mathrm{CONH}_{2}, x_{6}, x_{6}-$ \\
\hline $\mathrm{MS}^{3}$ of $[\mathrm{M}+\mathrm{H}]^{+}$ & $\begin{array}{c}\Delta \mathrm{H}_{2} \mathrm{O}, x_{6}, x_{6}-\mathrm{NH}_{3}, b_{6}, x_{5}-\mathrm{NH}_{3}, b_{5} \text { or } \mathrm{AA}(\mathrm{pY}) \mathrm{AA}, x_{4}-\mathrm{NH}_{3}, \\
\mathrm{~A}(\mathrm{pY}) \mathrm{AA} \text { or } \mathrm{AA}(\mathrm{pY}) \mathrm{A},\{\mathrm{A}(\mathrm{pY}) \mathrm{AA} \text { or } \mathrm{AA}(\mathrm{pY}) \mathrm{A}\}-30, \mathrm{~A}(\mathrm{pY}) \mathrm{A} \text { or } \\
\mathrm{AA}(\mathrm{pY}) \text { or }(\mathrm{pY}) \mathrm{AA},\{\mathrm{A}(\mathrm{pY}) \mathrm{A} \text { or } \mathrm{AA}(\mathrm{pY}) \text { or }(\mathrm{pY}) \mathrm{AA}\}-30, \mathrm{~A}(\mathrm{pY}) \text { or } \\
(\mathrm{pY}) \mathrm{A}, x_{3}, x_{3}-\mathrm{NH}_{3}, b_{3}\{\mathrm{~A}(\mathrm{pY}) \text { or }(\mathrm{pY}) \mathrm{A}\}-30\end{array}$ & 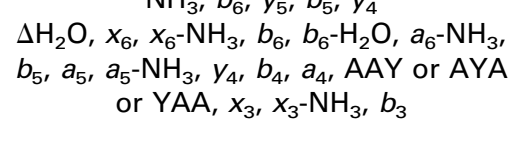 \\
\hline $\mathrm{MS}^{2}$ of $[\mathrm{M}+\mathrm{Na}]^{+}$ & $\begin{array}{c}\Delta \mathrm{NH}_{3}, \Delta \mathrm{H}_{2} \mathrm{O}, \Delta\left(\mathrm{HN}_{3}+\mathrm{H}_{2} \mathrm{O}\right), x_{6}, \Delta 80, y_{6}, b_{6}, \Delta 98, x_{5} \text { or } a_{6}, \mathbf{x}_{6^{-}} \\
80, y_{5} \text { or } c_{5}, b_{5}, a_{5} \text { or } x_{4}, y_{4} \text { or } c_{4}, b_{4} \text { or } \mathrm{A}(\mathrm{pY}) \mathrm{AA} \text { or } \mathrm{AA}(\mathrm{pY}) \mathrm{A} \\
\mathbf{a}_{5}-80 \text { or } \mathbf{x}_{4}-80, \mathbf{a}_{5}-98 \text { or } \mathbf{x}_{4^{-}}-98\end{array}$ & $\begin{array}{l}\Delta \mathrm{NH}_{3}, \Delta \mathrm{H}_{2} \mathrm{O}, \Delta\left(\mathrm{NH}_{3}+\mathrm{H}_{2} \mathrm{O}\right), \Delta \mathrm{CONH}_{2}, \\
\quad x_{6}, y_{6}, b_{6}, a_{6}, y_{5}, b_{5}, a_{5}, y_{4}, b_{4}, a_{4}\end{array}$ \\
\hline $\begin{array}{l}\mathrm{MS}^{2} \text { of }[\mathrm{M}+\mathrm{K}]^{+} \\
\mathrm{MS}^{2} \text { of }[\mathrm{M}-\mathrm{H}+2 \mathrm{Na}]^{+}\end{array}$ & $\begin{array}{c}\Delta \mathrm{H}_{2} \mathrm{O}, \Delta\left(\mathrm{NH}_{3}+\mathrm{H}_{2} \mathrm{O}\right), x_{6}, y_{6}, \Delta \mathbf{8 0}, b_{6}, \Delta \mathbf{9 8}, a_{6} \text { or } x_{5}, c_{5} \text { or } y_{5} \\
b_{5}, a_{5} \text { or } x_{4}, \mathbf{x}_{6}-80, c_{4} \text { or } y_{4}, b_{4}, a_{4} \\
\Delta \mathrm{H}_{2} \mathrm{O}, \Delta \mathrm{NaPO}_{3}, \Delta\left(\mathrm{NaPO}_{4}+\mathrm{H}_{2} \mathrm{O}\right), y_{4} \text { or } c_{4}, a_{5} \text { or } x_{4}, b_{4}\end{array}$ & $\begin{array}{c}\Delta \mathrm{H}_{2} \mathrm{O}, \Delta\left(\mathrm{NH}_{3}+\mathrm{H}_{2} \mathrm{O}\right), \Delta \mathrm{CONH}_{2}, b_{6}, y_{5} \\
b_{5}, a_{6}, y_{4}, b_{4}, c_{4} \\
\text { not available }\end{array}$ \\
\hline & & \\
\hline
\end{tabular}

$m / z$ 710. The sodiated $y_{7}$ ion is a result of cleavage $\mathrm{C}$-terminal to the aspartic acid residue. Although a sodiated $b_{6}$ ion is present at $m / z 493$, it is of relatively low intensity, suggesting that cleavage at this site favors rearrangement to form the sodiated $y_{7}$ over the sodiated $b_{6}$ ion. Beauchamp and coworkers showed that sodiated peptides undergo cleavage C-terminal to an aspartic acid residue [31]. They proposed a zwitterionic peptide that forms a salt-bridge between the carboxylate of the aspartic acid and the sodium ion, leaving a "mobile proton" to transfer within the peptide, facilitating charge-induced fragmentation under CID conditions. The mobile proton model, developed by Wysocki and coworkers [32-35], describes charge-induced fragmentations of protonated peptides that result from rapid intramolecular proton transfers occuring upon collisional activation of the molecule.

Figure $2 \mathrm{~b}$ is the $\mathrm{MS}^{3}$ spectrum of the sodiated $y_{7}$ ion of AAAAADAA(pY)AAAA at $m / z$ 710. This ion was selected for fragmentation to determine whether or not a loss of $98 \mathrm{Da}$ would be observed in a peptide fragment that did not contain an acidic residue. The major fragment ions observed in this spectrum correspond to the loss of $\mathrm{H}_{2} \mathrm{O}$ at $m / z 692$, the loss of $\mathrm{HPO}_{3}$ at $m / z 630$ and the loss of $\mathrm{HPO}_{3}+\mathrm{H}_{2} \mathrm{O}(98 \mathrm{Da})$ at $m / z$ 612. In this case, it is likely that $\mathrm{H}_{2} \mathrm{O}$ is eliminated from the Cterminal carboxy-group via a retro-Koch type of reaction as described by Harrison et al. [36, 37].

The peptides, AAAYAAA- $\mathrm{NH}_{2}$ and AAA(pY)AAA $\mathrm{NH}_{2}$ were studied in order to evaluate the differences in fragmentation between non-phosphorylated and phosphorylated protonated and metal-cationized peptide ions. The C-termini of these peptides were amidated in order to prevent direct peptide dehydration from the C-terminus. A summary of the CID fragmentations of these peptides is presented in Table 1. Figure $3 a$ is the MS/MS spectrum of the $[\mathrm{M}+\mathrm{H}]^{+}$ion of AAAYAAANH ${ }_{2}$ at $m / z$ 607. This spectrum demonstrates that the protonated peptide ion does not undergo extensive backbone fragmentation. In addition, the fragmentation spectrum does not reveal a direct loss of $\mathrm{H}_{2} \mathrm{O}$ from the peptide. The major fragment ion at $m / z 590$ is a result of a loss of $\mathrm{NH}_{3}$ from the peptide ion.

Figure $3 b$ is the MS/MS spectrum of the $[\mathrm{M}+\mathrm{Na}]^{+}$ ion at $m / z$ 629. The degree of backbone fragmentation of this ion is increased over that of the protonated ion. In addition, the most intense fragment peak, located at $m / z$ 611, suggests that dehydration of this molecule occurs as a result of loss of oxygen from the peptide backbone. Water loss from the tyrosine residue is unlikely, due to the resonance stabilization of the phenolic oxygen. These findings are in agreement with those of Gaskell et al., describing dehydration of peptide ions under CID conditions [38], where loss of water from the peptide backbone is common, while dehydration from a tyrosine side chain is unlikely. Reid and coworkers [39] later went on to describe the mechanism of water loss from the peptide backbone to occur via a retro-Ritter reaction, where protonation of the carbonyl oxygen on an amide followed by proton transfer from the amide nitrogen to the protonated carbonyl resulted in the subsequent loss of water and the formation of a nitrilium ion. The presence of the sodiated fragment ions, $y_{4}$ at $m / z 416$, $b_{4}$ at $m / z 399$ and $a_{4}$ at $m / z 371$, as well as the presence of low intensity sodiated fragment ions $c_{3} / y_{3}$ at $m / z$ 253 and $b_{3}$ at $m / z 237$ suggests that the sodium resides on the molecule directly $\mathrm{C}$-terminal or N-terminal to the tyrosine residue.

Similar fragmentation patterns are evident in the MS/MS spectrum of the $[\mathrm{M}+\mathrm{K}]^{+}$shown in Figure 3c. Either the peptide is preferentially cationized at a position close to the tyrosine residue during ionization, or a process of rearrangements occur during CID that promote backbone fragmentation until the cation reaches a position near the tyrosine residue. Tandem mass spectrometry of alkali metal cationized peptides has been described extensively by Gross [40, 41], Adams [42,43], Russell [44,45], and Tang [46]. Russell [45] suggested that the sodium ion interacted with the amino terminus or the amide nitrogen in a small tyrosine containing peptide. Gross $[40,41]$ and Tang 

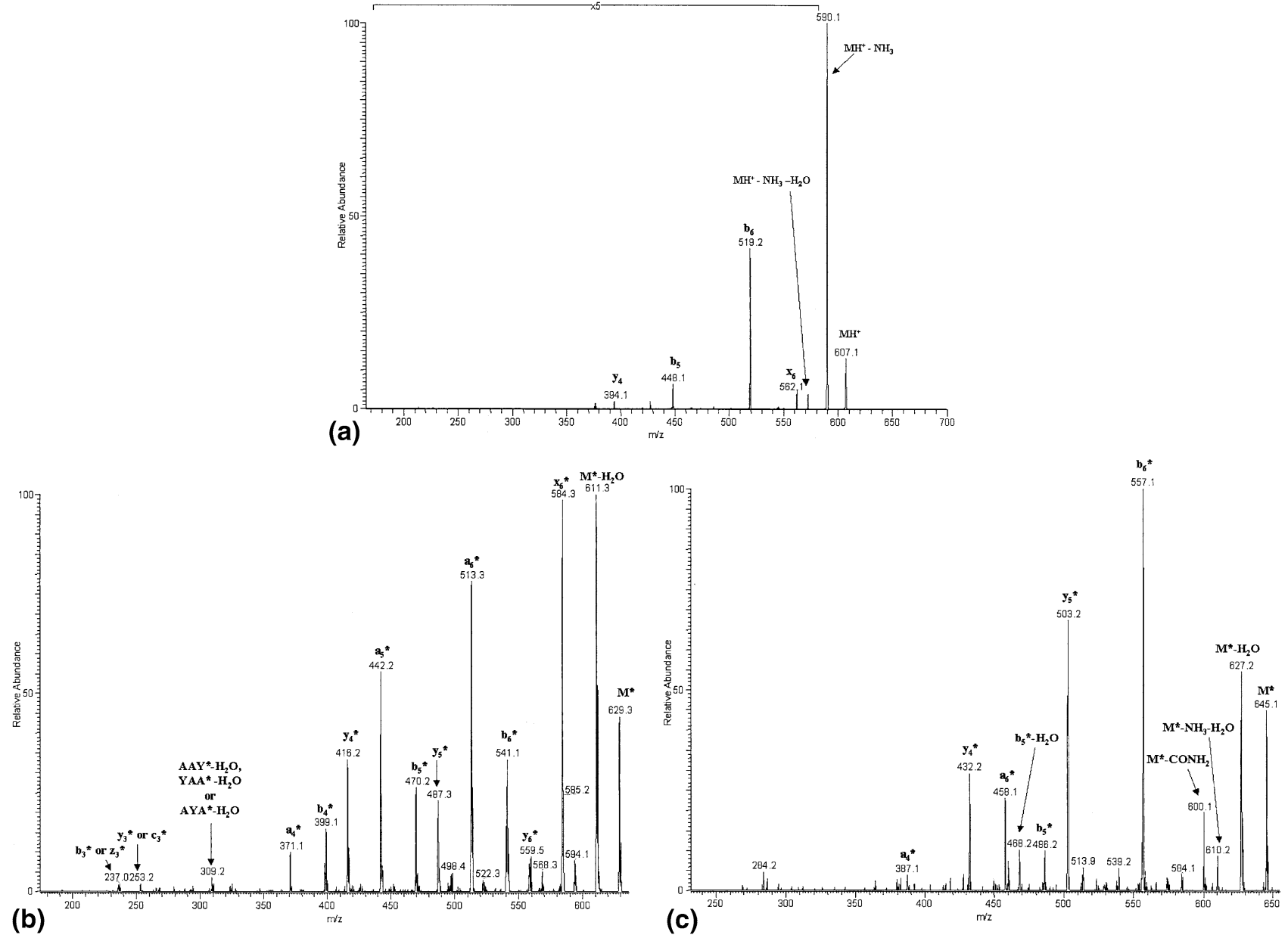

Figure 3. (a) $\mathrm{MS}^{2}$ of the $[\mathrm{M}+\mathrm{H}]^{+}$ion of AAAYAAA- $\mathrm{NH}_{2}$ at $m / z$ 607. (b) $\mathrm{MS}^{2}$ of the $[\mathrm{M}+\mathrm{Na}]^{+}$ion of AAAYAAA- $\mathrm{NH}_{2}$ at $m / z 629$. The asterisks $\left(^{*}\right)$ indicate a sodiated ion. (c) $\mathrm{MS}^{2}$ of the $[\mathrm{M}+\mathrm{K}]^{+}$ion of AAAYAAA- $\mathrm{NH}_{2}$ at $m / z 645$. The asterisks $\left.{ }^{*}\right)$ indicate a potassiated ion.

[46] proposed that metal cation binding occurs at the carbonyl oxygens of the $\mathrm{C}$-terminus and the adjoining amino acid residue; upon collisional activation, rearrangement of the alkali metal cationized peptide and subsequent expulsion of the C-terminal residue ensues. Furthermore, Gross [41] described metal cationized peptide fragments where the cation was stabilized by aromatic sidechains within the peptide sequence.

Figure $4 \mathrm{a}$ is the MS/MS spectrum of the $[\mathrm{M}+\mathrm{H}]^{+}$ion of AAA(pY)AAA- $\mathrm{NH}_{2}$ and Figure $4 \mathrm{~b}$ is the MS ${ }^{3}$ spectrum of the $\left[\mathrm{M}+\mathrm{H}-\mathrm{NH}_{3}\right]^{+}$fragment ion. Although several peaks, corresponding to backbone fragments are present, there is no evidence of loss of $\mathrm{HPO}_{3}$ from the phosphotyrosine residue, thus accentuating the inherent stability of this particular site under low energy CID conditions. Scheme 1a summarizes the major fragmentations that occur in the CID spectra of the $[\mathrm{M}+\mathrm{H}]^{+}$and $\left[\mathrm{M}+\mathrm{H}-\mathrm{NH}_{3}\right]^{+}$ions of AAA(pY)AAANH ${ }_{2}$.

However, when the MS/MS spectrum of the $[\mathrm{M}+\mathrm{Na}]^{+}$ion of $\mathrm{AAA}(\mathrm{pY}) \mathrm{AAA}-\mathrm{NH}_{2}$ was acquired
(Figure 5a), losses of $\mathrm{H}_{2} \mathrm{O}\left(\mathrm{m} / \mathrm{z}\right.$ 691), $\mathrm{HPO}_{3}(\mathrm{~m} / \mathrm{z} 629)$ and $\mathrm{HPO}_{3}+\mathrm{H}_{2} \mathrm{O}(\mathrm{m} / \mathrm{z} 611)$ were observed. There are no major differences in the types of backbone fragmentation observed for the sodiated ions of the non-phosphorylated and the phosphorylated peptides. But, the presence of sodiated $\left(a_{5} / x_{4}-80\right)$ and $\left(a_{5} / x_{4}-98\right)$ ions supports the hypothesis that the sodium ion initially orients itself or rearranges to a position near the phosphotyrosine residue. Scheme $1 \mathrm{~b}$ summarizes the major fragmentations present in the MS/MS spectrum of the $[\mathrm{M}+\mathrm{Na}]^{+}$ion of AAA(pY)AAA- $\mathrm{NH}_{2}$.

Figure $5 \mathrm{~b}$ is the MS/MS spectrum of the $[\mathrm{M}-\mathrm{H}+2 \mathrm{Na}]^{+}$ion of AAA(pY)AAA- $\mathrm{NH}_{2}$ at $m / z$ 731. As seen in this spectrum, major fragmentations associated with losses of $\mathrm{H}_{2} \mathrm{O}\left(\mathrm{m} / z\right.$ 713), $\mathrm{NaPO}_{3}\left(\mathrm{~m} / z\right.$ 629) and $\mathrm{H}_{2} \mathrm{O}$ $+\mathrm{NaPO}_{3}(\mathrm{~m} / \mathrm{z}$ 611) are generated. From this data, it can be surmised that the second sodium is located on the phosphotyrosine side chain in the form of a sodium salt with a deprotonated phosphate oxygen. In addition, backbone fragmentation of this ion essentially does not occur. There are a few very minor singly charged, doubly sodiated ions: $b_{4}$ at $m / z 501, y_{4} / c_{4}$ at $m / z 518$ and 


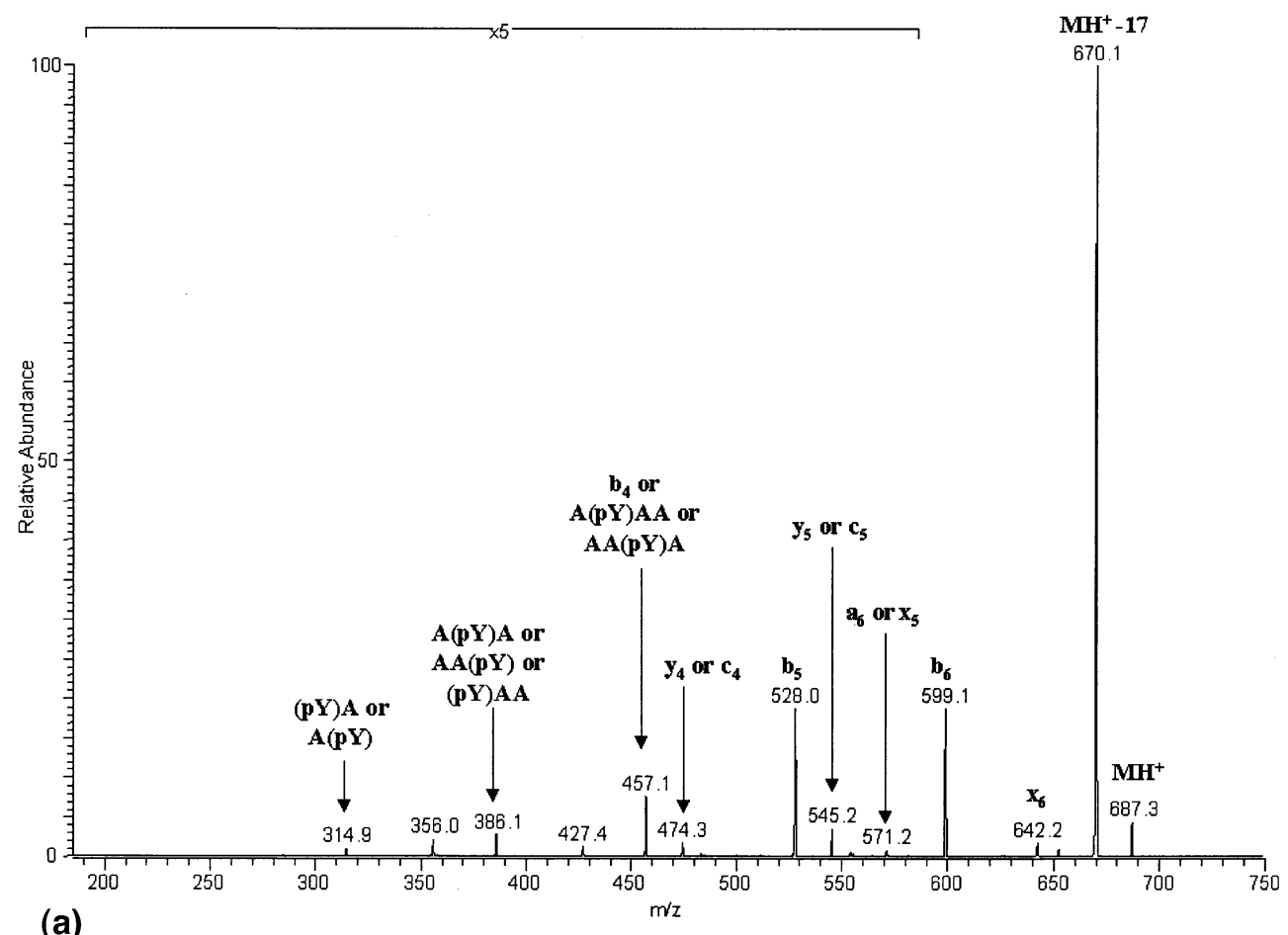

(a)

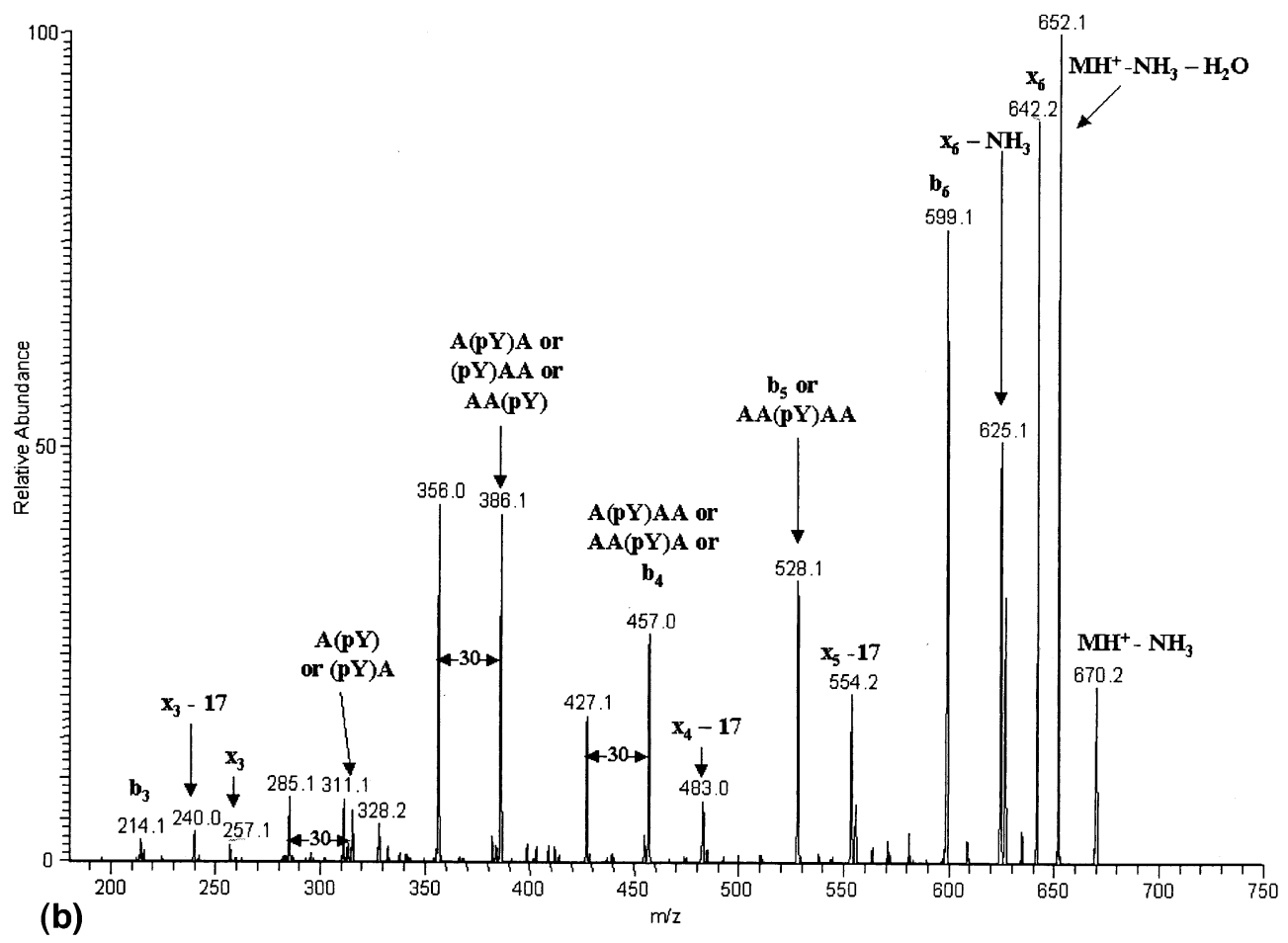

Figure 4. (a) $\mathrm{MS}^{2}$ of the $[\mathrm{M}+\mathrm{H}]^{+}$ion of $\mathrm{AAA}(\mathrm{pY}) \mathrm{AAA}-\mathrm{NH}_{2}$ at $m / z$ 687. (b) $\mathrm{MS}^{3}$ of the $[\mathrm{M}+\mathrm{H}]^{+}$ion of AAA(pY)AAA- $\mathrm{NH}_{2}$ at $m / z 670$.

$a_{4} / x_{4}$ at $m / z 544$. These fragmentations are presented in Scheme 1c.

Figure $5 \mathrm{c}$ is the MS/MS spectrum of the $[\mathrm{M}+\mathrm{K}]^{+}$ion of $\mathrm{AAA}(\mathrm{pY}) \mathrm{AAA}-\mathrm{NH}_{2}$ at $m / z$ 725. Fragment ions in this spectrum with the greatest intensity correspond to the loss of $\mathrm{H}_{2} \mathrm{O}$ at $m / z 707$ and to the potassiated $\left(x_{6}-80\right)$ ion at $m / z 600$. The presence of the minor potassiated fragmentation ions of $\left(b_{4}-98\right)$ at $m / z 397,(\mathrm{pY})$ at $m / z 300$ 


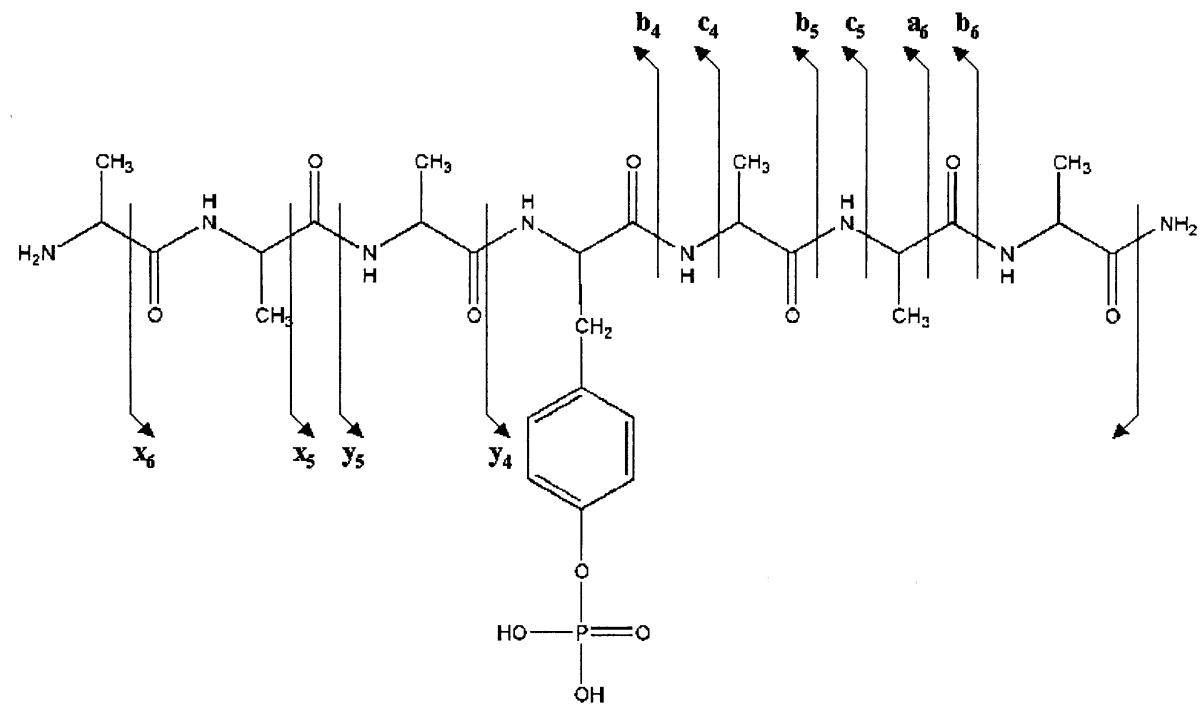

(a)

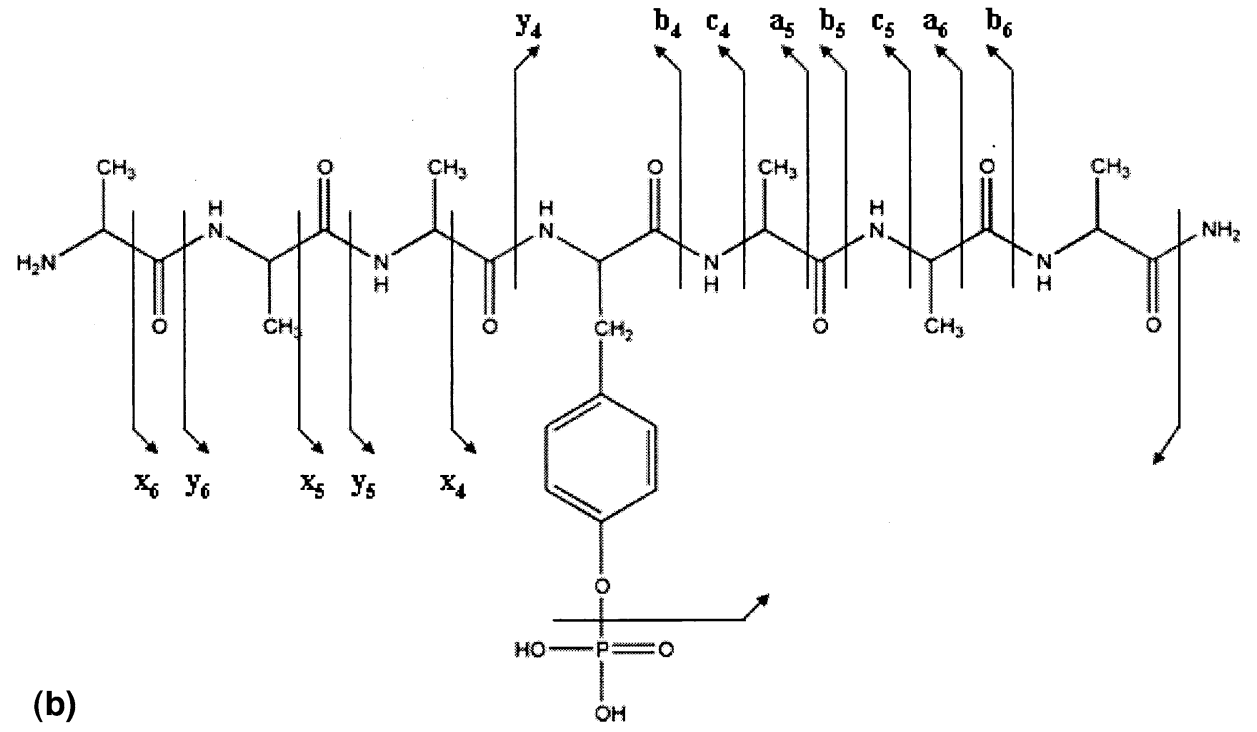

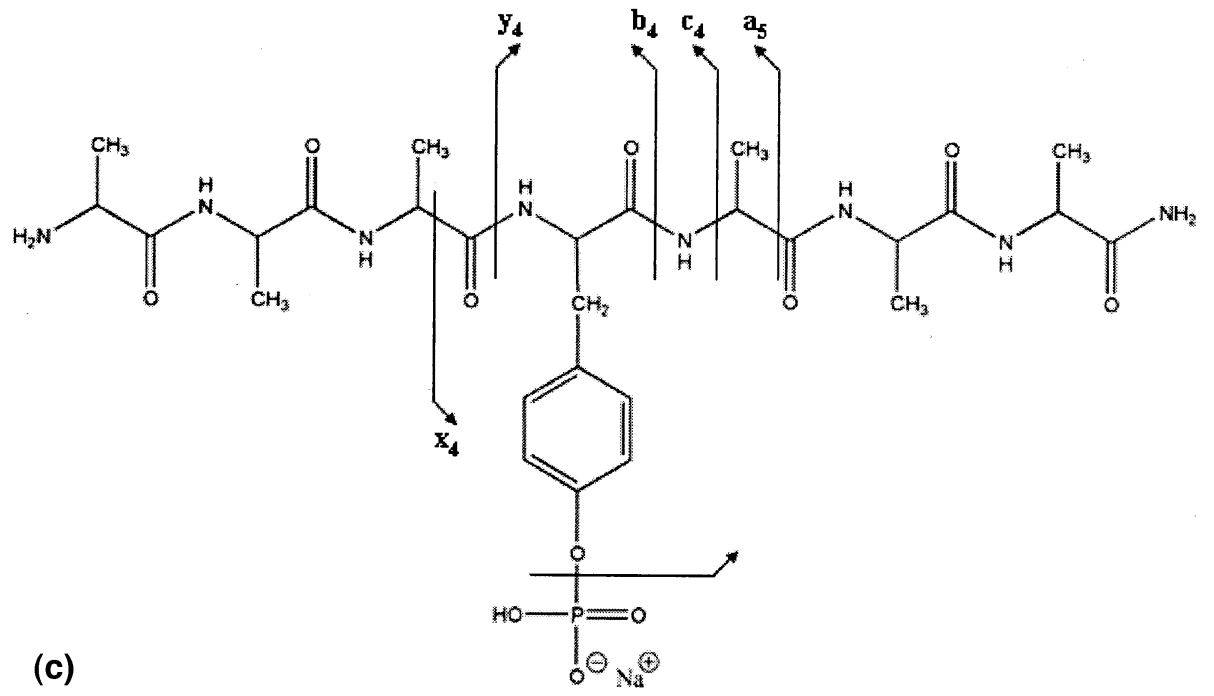

Scheme 1. (a) CID fragments of the $[\mathrm{M}+\mathrm{H}]^{+}$ion of AAA(pY)AAA-NH $\mathrm{H}_{2}$ (b) CID fragments of the $[\mathrm{M}+\mathrm{Na}]^{+}$ion of AAA(pY)AAA- $\mathrm{NH}_{2}$. Enhancement of backbone fragmentation, as well as loss of $\mathrm{HPO}_{3}$ from the phosphotyrosine side chain is evident. (c) CID fragments of the $[\mathrm{M}-\mathrm{H}+2 \mathrm{Na}]^{+}$ion of $\mathrm{AAA}(\mathrm{pY}) \mathrm{AAA}-\mathrm{NH}_{2}$. Addition of the second sodium causes a reduction in backbone fragmentation. Loss of $102 \mathrm{Da}$, corresponding to a loss of $\mathrm{NaPO}_{3}$, identifies the location of the second sodium to be on the phosphate group of the phosphotyrosine side chain. 


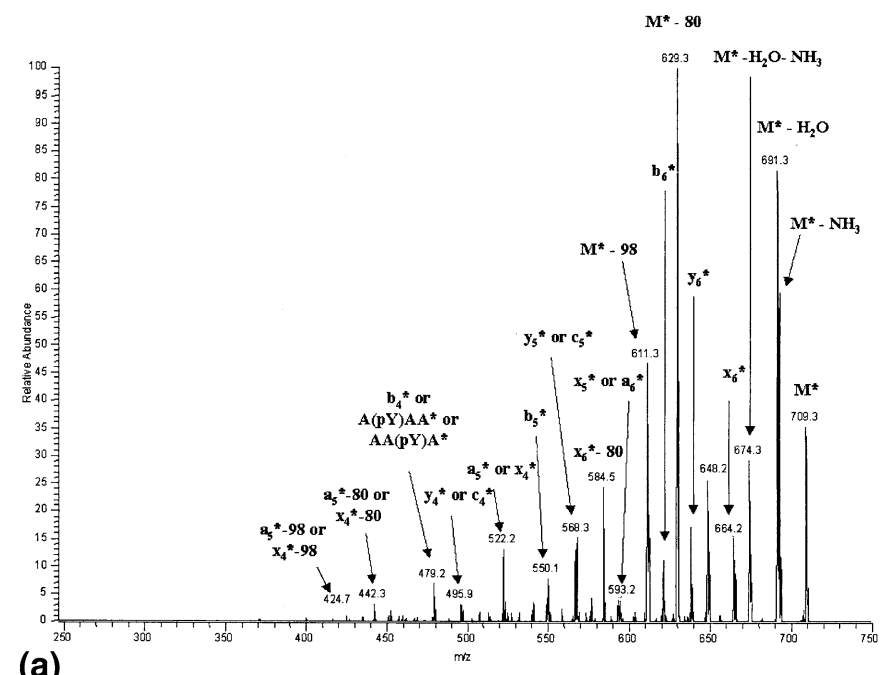

(a)
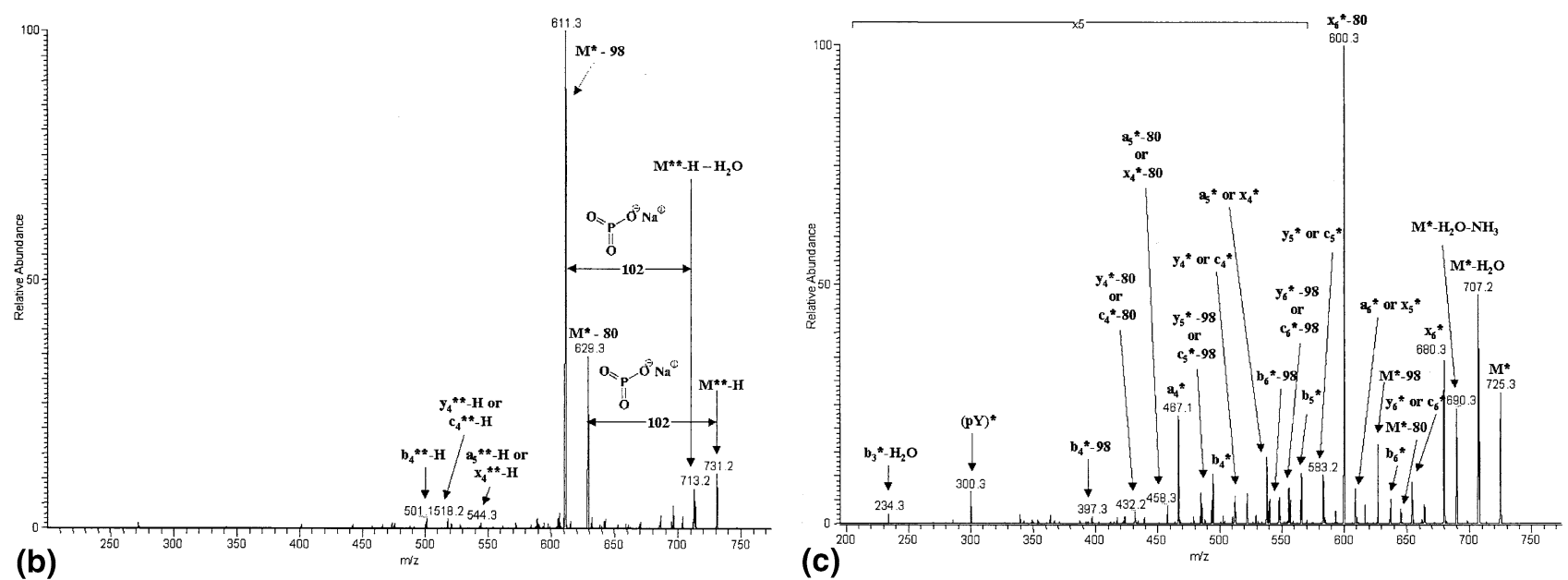

Figure 5. (a) $\mathrm{MS}^{2}$ of the $[\mathrm{M}+\mathrm{Na}]^{+}$ion of $\mathrm{AAA}(\mathrm{pY}) \mathrm{AAA}-\mathrm{NH}_{2}$ at $m / z$ 709. The asterisks $(*)$ indicate a sodiated ion. (b) $\mathrm{MS}^{2}$ of the $[\mathrm{M}-\mathrm{H}+2 \mathrm{Na}]^{+}$ion of AAA(pY)AAA-NH${ }_{2}$ at $m / z 731$. The asterisks (*) indicates a sodiated ion and a double asterisks $\left({ }^{* *}\right)$ indicates a singly charged doubly sodiated ion. (c) $\mathrm{MS}^{2}$ of the $[\mathrm{M}+\mathrm{K}]^{+}$ion of AAA(pY)AAA- $\mathrm{NH}_{2}$ at $m / z 725$. The asterisks $\left(^{*}\right)$ indicate a potassiated ion.

and $\left(b_{3}-\mathrm{H}_{2} \mathrm{O}\right)$ at $\mathrm{m} / \mathrm{z} 234$, suggests the initial presence or the rearrangement of the potassium to a position near the phosphotyrosine residue.

The gas-phase fragmentation of $\mathrm{HPO}_{3}(80 \mathrm{Da})$ and $\mathrm{HPO}_{3}+\mathrm{H}_{2} \mathrm{O}(98 \mathrm{Da})$ from of sodium and potassium cationized phosphotyrosine peptides is similar to that observed in the CID spectra of protonated phosphotyrosine peptides containing arginine or lysine residues. The data suggests that this is a loss of $\mathrm{HPO}_{3}$ from the phosphotyrosine residue and $\mathrm{H}_{2} \mathrm{O}$ from the peptide. It is likely that the CID fragmentations associated with backbone cleavage and dehydration of the peptide ions are the result of charge-induced fragmentations initiated by a "mobile proton". Backbone cleavages in protonated peptides typically result from protonation at the site of cleavage [34]. Loss of water from the peptide is likely to occur via a retro-Ritter reaction, as described by Reid et al. [39] or a retro-Koch reaction described by Harrison and coworkers [36,37] and by Hunt et al. [47]. These reactions require protonation of either a carbonyl oxygen or a C-terminal carboxylic acid, with dehydration occurring when a mobile proton is transferred to the site of the protonated oxygen [39].

We propose that loss of $\mathrm{HPO}_{3}$ from the alkali metal cationized phosphotyrosine containing peptide is due to the close proximity of the metal cation to the phosphotyrosine residue. Collisional activation of the phosphotyrosine containing peptide in the presence of a charge, in this case sodium or potassium, favors fragmentation between the phenolic oxygen and the phosphorous by proton transfer from a phosphate oxygen to the phenolic oxygen and subsequent elimination of the neutral $\mathrm{HPO}_{3}$. Schemes $2 \mathrm{a}$ and $2 \mathrm{~b}$ present two possible coordinations of a sodium ion with a phosphotyrosine containing peptide. The fragment ion spectrum of alkali metal cationized peptide, AAAYAAA- $\mathrm{NH}_{2}$, showed a major loss of $\mathrm{H}_{2} \mathrm{O}$ from 
<smiles>[R3]C(N)C(=O)N[C@@H](Cc1ccc(OP(=O)(O)O)cc1)C(=O)N[C@@H](C)C(=O)O</smiles><smiles>[R3]C(N)C(=O)NC(Cc1ccc(OP(=O)(O)O)cc1)C(=O)NC([Y])C([R8])N</smiles>

Scheme 2. (a) Possible orientation of a sodium ion on a phosphotyrosine containing peptide. Interaction of the sodium ion with a carbonyl oxygen is stabilized by the aromatic ring of the phosphotyrosine side chain. (b) Possible orientation of a sodium ion on a phosphotyrosine containing peptide. Interaction of the sodium ion with a carbonyl oxygen and an amide nitrogen with stabilization by the aromatic ring of the phosphotyrosine side chain. The interaction with both the carbonyl oxygen and the amide nitrogen could result in a proton residing on the peptide backbone.

the peptide ion. This would suggest that the losses of 80 and 98 Da observed in the alkali metal cationized peptide, $\mathrm{AAA}(\mathrm{pY}) \mathrm{AAA}-\mathrm{NH}_{2}$, would be the result of loss of $\mathrm{HPO}_{3}$ and $\mathrm{HPO}_{3}+\mathrm{H}_{2} \mathrm{O}$, respectively, rather than the concerted loss of $\mathrm{H}_{3} \mathrm{PO}_{4}(98 \mathrm{Da})$ from the phosphotyrosine residue.

\section{Conclusions}

Sodium and potassium cationized phosphotyrosine peptides undergo fragmentation in their CID spectra similar to that observed in the CID spectra of protonated phosphotyrosine peptides containing arginine or lysine residues. In many cases the loss of $98 \mathrm{Da}$ is observed. This type of fragmentation pattern proved to be confusing as it corresponds to a loss of $\mathrm{H}_{3} \mathrm{PO}_{4}$, a fragmentation typically associated with dephosphorylation of an aliphatic side chain (serine and threonine). The data suggests that loss of $98 \mathrm{Da}$ from aromatic phosphorylation is actually a loss of $\mathrm{HPO}_{3}$ from the phosphotyrosine residue and $\mathrm{H}_{2} \mathrm{O}$ from the peptide. It is likely that the fragmentations associated with backbone cleavage and dehydration of the peptide ions are the result of charge-induced fragmentations initiated by a "mobile proton." Loss of water from the peptide is likely to occur via a retro-Ritter reaction, as described by Reid et al. [39] or a retro-Koch reaction described by Harrison and coworkers [36,37] and by Hunt et al. [47]. We propose that loss of $\mathrm{HPO}_{3}$ from the phosphotyrosine residue is the result of the proximity of the alkali metal ion to the phosphotyrosine residue, where the presence of a charge, in this case a sodium or potassium ion, favors CID fragmentation between the phenolic oxygen and the phosphorous. This fragmentation likely occurs due to an intramolecular proton transfer from an acidic hydrogen located on a phosphate oxygen to the phenolic oxygen, resulting in subsequent elimination of the neutral $\mathrm{HPO}_{3}$.

\section{Acknowledgments}

The authors thank the reviewers for their intellectual input regarding this manuscript. Funding for this work was provided by a contract (DABT63-99-1-0006) to RJC from the Defense Advanced Research Project Agency (DARPA). Support for SCM was provided by a NSF-GOALI grant (CHE 9634238). CEV is supported by a NIH Training Grant in Anti-Cancer Drug Development (CA 09243).

\section{References}

1. Aebersold, R.; Goodlett, D. R. Mass Spectrometry in Proteomics. Chem. Reveiw. 2001, 101, 269-295.

2. Mann, M.; Hendrickson, R. C.; Pandey, A. Analysis of Proteins and Proteomes by Mass Spectrometry. Annu. Rev. Biochem. 2001, 70, 437-473.

3. Chalmers, M. J.; Gaskell, S. J. Advances in Mass Spectrometry for Proteome Analysis. Curr. Opin. Biotech. 2000, 11, 384-390.

4. Reid, G. E.; Simpson, R. J.; O'Hair, R. A. J. Leaving Group and Gas Phase Neighboring Group Effects in the Side Chain Losses from Protonated Serine and its Derivatives. J. Am. Soc. Mass Spectrom. 2000, 11, 1047-1060.

5. Annan, R. S.; Carr, S. A. Phosphopeptide Analysis by MatrixAssisted Laser Desorption Time-of-Flight Mass Spectrometry. Anal. Chem. 1996, 68, 3413-3421.

6. Busman, M.; Schey, K. L.; Oatis, J. E.; Knapp, D. R. Identification of Phosphorylation Sites in Phosphopeptides by Positive and Negative Mode Electrospray Ionization-Tandem Mass Spectrometry. J. Am. Soc. Mass Spectrom. 1996, 7, 243-249. 
7. Qin, J.; Chait, B. T. Identification and Characterization of Posttranslational Modifications of Proteins by MALDI Ion Trap Mass Spectrometry. Anal. Chem. 1997, 69, 4002-4009.

8. DeGnore, J. P.; Qin J. Fragmentation of Phosphopeptides in and Ion Trap Mass Spectrometer. J. Am. Soc. Mass Spectrom. 1998, 9, 1175-1188.

9. Zhang, X.; Herring, C. J.; Romano, P. R.; Szczepanowska, J.; Brzeska, H.; Hinnebusch, A. G.; Qin, J. Identification of Phosphorylation Sites in Proteins Separated by Polyacrylamide Gel Electrophoresis. Anal. Chem. 1998, 70, 2050-2059.

10. Tholey, A.; Reed, J.; Lehmann, W. D. Electrospray Tandem Mass Spectrometric Studies of Phosphopeptides and Phosphopeptide Analogues. J. Mass Spectrom. 1999, 34, 117-123.

11. Hoffmann, R.; Metzger, S.; Spengler, B.; Otvos, L. Sequencing of Peptides Phosphorylated on Serines and Threonines by Post-source Decay in Matrix-assisted Laser Desorption/Ionization Time-of-flight Mass Spectrometry. J. Mass Spectrom. 1999, 34, 1195-1204.

12. Metzger, S.; Hoffmann, R. Studies on the Dephosphorylation of Phosphotyrosine-Containing Peptides During Post-Source Decay in Matrix-Assisted Laser Desorption/Ionization. J. Mass Spectrom. 2000, 35, 1165-1177.

13. Huddleston, M. J.; Annan, R. S.; Bean, M. F.; Carr, S. A. Selective Detection of Phosphopeptides in Complex Mixtures by Electrospray Liquid Chromatography/Mass Spectrometry. J. Am. Soc. Mass Spectrom. 1993, 4, 710-717.

14. Dass, C.; Mahalakshmi, P. Amino Acid Sequence Determination of Phosphoenkephalins Using Liquid Secondary Ionization Mass Spectrometry. Rapid Commun. Mass Spectrom. 1995, 9, 1148-1154.

15. Gibson, B. W.; Cohen, P. Liquid Secondary Ion Mass Spectrometry of Phosphorylated and Sulfated Peptides and Proteins. Methods Enzymol. 1990, 193, 480-501.

16. Cohen, P.; Gibson, B. W.; Holmes, C. F. Analysis of the in Vivo Phosphorylation States of Proteins by Fast Atom Bombardment Mass Spectrometry and Other Techniques. Methods Enzymol. 1991, 201, 153-168.

17. Carr, S. A.; Huddleston, M. J.; Annan, R. S. Selective Detection and Sequencing of Phosphopeptides at the Femtomole Level by Mass Spectrometry. Anal. Biochem. 1996, 239, 180-192.

18. Spengler, B. Post-Source decay Analysis in Matrix Assisted Laser Desorption/Ionization Mass Spectrometry of Biomolecules. J. Mass Spectrom. 1997, 32, 1019.

19. Moyer, S. C.; Cotter, R. J.; Woods, A. S. Fragmentation of Phosphopeptides by Atmospheric Pressure MALDI and ESI/ Ion Trap Mass Spectrometry. J. Am. Soc. Mass Spectrom. 2002, 13, 274-283.

20. Laiko, V. V.; Baldwin, M. A.; Burlingame, A. L. Atmospheric Pressure Matrix-Assisted Laser Desorption/Ionization Mass Spectrometry. Anal. Chem. 2000, 72, 652-657.

21. Laiko, V. V.; Moyer, S. C.; Cotter, R. J. Atmospheric Pressure MALDI/Ion Trap Mass Spectrometry. Anal. Chem. 2000, 72, 5239-5243.

22. Moyer, S. C.; Marzilli, L. A.; Woods, A. S.; Laiko, V. V.; Doroshenko, V. M.; Cotter, R. J. Atmospheric Pressure Matrix Assisted Laser Desorption/Ionization (AP MALDI) on a Quadrupole Ion Trap Mass Spectrometer. Int. J. Mass Spectrom. 2003, 226, 133-150.

23. Moyer, S.C.; Cotter, R. J. Atmospheric Pressure MALDI. Anal. Chem., 2002, 74, 469A-476A.

24. Von Seggern, C. E.; Moyer, S. C.; Cotter, R.J. Liquid Infrared Atmospheric Pressure MALDI/Ion Trap Mass Spectrometry of Sialylated Carbohydrates. Anal. Chem. (in press).

25. Moyer, S.C.; Woods, A.S; Cotter, R.J. "Fragmentation of Phosphotyrosine Containing Peptides by Atmospheric Pressure MALDI Ion Trap Mass Spectrometry." Presented at the 2nd Mass Spectrometry Conference Applied to Biological Warfare Agents, Warwick, UK, April 2002.

26. Adams, J. Charge Remote Fragmentations: Analytical Applications and Fundamental Studies. Mass Spectrom. Rev. 1990, 9, 141-186.

27. Adams, J.; Songer M.J. Charge Remote Fragmentations for Structural Determination of Lipids. Trends Anal. Chem. 1993, $12,28-36$.

28. Gross, M.L. Charge Remote Fragmentations: Method, Mechanisms and Applications. Int. J. Mass Spectrom. Ion Processes 1992, 118/119, 137-165.

29. Cheng, C.; Gross, M.L. Applications and Mechanisms of Charge-Remote Fragmentation. Mass Spectrom. Rev. 2000, 19, 398-420.

30. Gross, M.L. Charge-remote Fragmentation: An Account of Research on Mechanisms and Applications. Int. J. Mass Spectrom. 2000, 200, 611-624.

31. Lee, S.-W.; Kim, H.S.; Beauchamp, J.L. Salt Bridge Chemistry Applied to Gas-Phase Peptide Sequencing: Selective Fragmentation of Sodiated Gas-Phase Peptide Ions Adjacent to Aspartic Acid Residues. J. Am. Chem. Soc. 1998, 120, 3188-3195.

32. Gu, C.; Tsaprailis, G.; Breci, L.; Wysocki, V.H. Selective Gas-Phase Cleavage at the Peptide Bond C-Terminal to Aspartic Acid in Fixed-Charge Derivatives of Asp-Containing Peptides. Anal. Chem. 2000, 72, 5804-5813.

33. Tsaprailis, G.; Nair, H.; Somogyi, A.; Wysocki, V.H.; Zhong, W.; Futrell, J.H.; Summerfield, S.G.; Gaskell, S.J. Influence of Secondary Structure on the Fragmentation of Protonated Peptides. J. Am. Chem. Soc. 1999, 121, 5412-5154.

34. Wysocki, V.H.; Tsaprailis, G.; Smith, L.L.; Breci, L.A. Mobile and Localized Protons: A Framework for Understanding Peptide Dissociation. J. Mass Spectrom. 2000, 35, 1399-1406.

35. Tsaprailis, G.; Somogyi, A.; Nikolaev, E.N.; Wysocki, V.H. Refining the Model for Selective Cleavage at Acidic Residues in Arginine-Containing Protonated Peptides. Int. J. Mass Spectrom. 2000, 195/196, 467-479.

36. Yalcin, T.; Khou, C.; Csizmadia, I.G.; Peterson, M.R.; Harrison, A.G. Why are b Ions Stable Species in Peptide Spectra? J. Am. Soc. Mass Spectrom. 1995, 6, 1165-1174.

37. Yalcin, T.; Csizmadia, I.G.; Peterson, M.R.; Harrison, A.G. The Structure and Fragmentation of $b_{n}(n \geq 3)$ Ions in Peptide Spectra. J. Am. Soc. Mass Spectrom. 1996, 7, 233-242.

38. Ballard, K.D.; Gaskell, S. J. Dehydration of Peptide $[\mathrm{M}+\mathrm{H}]^{+}$ Ions in the Gas Phase. J. Am. Soc. Mass Spectrom. 1993, 4, $477-481$.

39. Reid, G.E.; Simpson, R.J.; O'Hair, R.A.J. A Mass Spectrometric and $\mathrm{Ab}$ Initio Study of the Pathways for Dehydration of Simple Glycine and Cysteine-Containing Peptide $[\mathrm{M}+\mathrm{H}]^{+}$ Ions. J. Am. Soc. Mass Spectrom. 1998, 9, 945-956.

40. Grese, R.P.; Gross, M.L. Gas-Phase Interactions of Lithium Ions and Dipeptides. J. Am. Chem. Soc. 1990, 112, 5098-5104.

41. Grese, R.P.; Cerny, R.L.; Gross, M.L. Metal Ion-Peptide Interactions in the Gas Phase: A Tandem Mass Spectrometry Study of Alkali Metal Cationized Peptides. J. Am. Chem. Soc. 1989, 111, 2835-2842.

42. Teesch, L.M.; Orlando, R.C.; Adams, J. Location of the Alkali Metal Atom in Gas-Phase Peptide Complexes. J. Am. Chem. Soc. 1991, 113, 3668-3675.

43. Teesch, L. M.; Adams, J. Fragmentations of Gas-Phase Complexes Between Alkali Metal Adams and Peptides: Metal Ion Binding to Carbonyl Oxygens and Other Neutral Functional Groups. J. Am. Chem. Soc. 1991, 113, 812-820.

44. Mallis, L.M.; Russell, D.H. Fast-Adam-Bombardment-Tandem Mass Spectrometry Studies of Alkali-Metal Ions of Small Peptides. Anal. Chem. 1986, 58, 1076-1080. 
45. Russell, D.H.; McGlohon, E.S.; Mallis, L.M. Fast-Atom Bombardment-Tandem Mass Spectrometry Studies of OrganoAlkali-Metal Ions of Small Peptides. Competitive interaction of Sodium with Basic Amino Acid Substituents. Anal. Chem. 1988, 60, 1818-1824.

46. Tang, X.; Ens, W.; Standing, K.G.; Westmore, J.B. Daughter Ion Mass Spectra from Cationized Molecules of Small Oligopep- tides in a Reflecting Time-of-Flight Mass Spectrometer. Anal. Chem. 1988, 60, 1791-1799.

47. Arnott D.; Kottmeier, K.; Yates, N.; Shabanowitz, J.; Hunt, D.F. Fragmentation of Multiply Protonated Peptides under Low Energy Conditions. Proceedings of the 42nd ASMS Conference on Mass Spectrometry, Chicago, 1994, 470 